\title{
Una Marson: feminism, anti-colonialism and a forgotten fight for freedom
}

\author{
Alison Donnell
}

When we think about the factors that have contributed to the beginnings of a West Indian British intellectual tradition, we would commonly bring to mind the towering figure of C. L. R. James and his comrades of the pre-Windrush generation, such as George Padmore. It would also be important to acknowledge the generation of nationalist writers and thinkers based in the Caribbean itself, such as Roger Mais and Victor Stafford Reid. We might also think of the BBC's Caribbean Voices which provided a much needed outlet, as well as a valuable source of income, for new writers and writings, and also, of course, of the talented community of male writers and intellectuals, such as George Lamming, Sam Selvon and V. S. Naipaul, who had come to London in the 1950s. Yet what is so commonly neglected in accounts of West Indian and black British literary and intellectual histories of the first half of the twentieth century is mention of Una Marson, a black Jamaican woman whose experiences and achievements provided a link to all these major movements and figures.

It is perhaps not surprising that Marson's identity as an intellectual is not straightforward. As an educated, middle-class daughter of a Baptist minister, Marson's intellectual development took place within the context of a religious home where the activities of playing music and reading poetry were prized, and the conservative and colonial Hampton High School where she received an 'English public-school education'.$^{1}$ However, as one of a small number of black scholarship girls, Marson was apprenticed in the operations of racism by the time she left school. As a woman, Marson's education was directed towards ideas of service rather than intellectual grandeur, and even the pupils of this prestigious school were encouraged towards teaching, nursing, helping their fathers in business and homemaking. When Marson left in 1922, her father had already died and she felt that she needed to support her mother. She had directed her studies towards commerce 


\section{UNA MARSON}

and secretarial work, and chose to take work with the Salvation Army and the YMCA, indicating that her understanding of service was already framed by ideas of social justice, ideas that would take her outside of the traditional spaces of middle-class women's work.

It is also clear that Marson's intellectual energy was never abstracted from her reading of a world in need of change, and it is easy to trace her determination to see her ideas translated into action. She did not pursue the conventional avenues to personal recognition but consistently sought to initiate and participate in collective action. However, this is not to say that Marson was able to translate all her ideas into a better social reality. As a woman she felt a responsibility to draw attention to both the problems and the possibilities facing other black women of her time, but her particular focus on issues of gender and women's liberation, alongside those of racial equality and cultural nationalism, meant that she was challenging structures of inequality that were commonly regarded as less urgent and less central in the intellectual and political agendas of her time.

This chapter will offer a reading of Marson's intellectual positions as articulated in her journalism and speeches, and seek to explore to what extent she was able to use her travelling between London and Kingston to reconfigure her political understanding and cultural projects in each location through an understanding of the other. Work to date has tended to examine Marson's creative works, four volumes of poetry and three plays, but there has been almost no scholarship that examines the politics of her journalism and public works. ${ }^{2}$ It is clearly no accident of history that Marson speaks more than she is spoken of, and therefore it is difficult to quantify her ability to bring about change in Britain and almost impossible to gauge how the British may have seen themselves anew through her work, especially as most of her articles were produced for a Jamaican audience. This chapter will position Marson's work as influential and radical in both a British and a West Indian context, and pay particular attention to the ways in which her life in Britain impacted upon her ideas relating to gender politics, cultural identity, nationalism and political organisation.

\section{London, Kingston and the world}

The people of England are gradually waking up. They have been uneducated about the coloured people for a long time but they are now beginning to wake up and learn about us. ${ }^{3}$

Life in Jamaica is dull and monotonous. Intellectual life does not find expression in any form of art, custom or even recreation. Anything that 


\section{ALISON DONNELL}

does not bear the hallmark of British is looked upon with suspicion ... I lay the blame at both doors, that of Great Britain and that of ourselves. ${ }^{4}$

Although Marson's arrival in London in 1932 coincided historically with that of C. L. R. James, the ideas and beliefs she brought with her set her apart from both the young - male - intellectuals of Trinidad in the 1930s and the later generation of emigrants in important ways. She had left Jamaica in the very year in which her first play, At What A Price, was staged in Kingston, to public acclaim. She had also, by the age of twenty-seven, established her journalistic credentials, founding in 1928 the monthly journal The Cosmopolitan: a monthly magazine for the business youth of Jamaica and the official organ of the Stenographers Association. Both her creative and her journalistic works already articulated her strong commitment to women's rights. Moreover, unlike the male writers who came to England, Marson did not seem to need, as Lamming so succinctly stated, to 'get out'. ${ }^{5}$ For her, the journeys to Britain were prompted more by an awareness of the need to see Jamaica as part of the larger colonial, Caribbean, and later African, picture. Indeed, despite the fact that her works register that she was often restless, frustrated and impatient with Jamaicans, she maintained a strong investment in Jamaica and in the establishment of a national cultural identity. In the first issue of The Cosmopolitan, published in May 1928, Marson stated that 'Our chief aim is to develop literary and other artistic talents in our Island ( $\mathrm{sic}$ ) home ... to encourage talented young people to express themselves freely'.

Indeed, London was not initially an open stage of opportunity for Marson and, as a black woman and a novice traveller, she was daunted by the hostility and the loneliness of the metropolis. Moreover, arriving in 1932, she came to Britain twenty years before mass immigration, before the flourishing of West Indian literary voices and before the recognised presence of a difference had 'creolised the metropole'. Her story cannot invoke the familiar images and narratives of shared crossings, of boats, railway stations and landladies. Rather its telling demands that we extend our history of this creolisation backwards, to account for the smaller but significant places of exchange and encounter between West Indians, Africans and Indians in Britain, such as the Florence Mills café in Oxford Street, London, run by Amy Ashwood Garvey from the early 1930s or the Ethiopian Teashop in Oxford Road, Manchester, run by Ras Makonnen from 1939, or, indeed, the home of Dr Harold Moody in Peckham, a fellow Jamaican, with whose family Marson lodged. ${ }^{6}$

Through Moody, Marson became involved with the League of Coloured Peoples, an organisation he had founded in 1931 to address 


\section{UNA MARSON}

the issues of racial division and prejudice and, through her work for the League and their journal, The Keys, she found both companionship and purpose. Throughout her life, it was an opportunity to advance her own learning and her deeply felt causes that carried Marson from place to place, and soon London was providing her with opportunities in both these directions. In her work for the League, Marson had met many African students, a smaller number of professionals and Nana Ofori Atta, a paramount chief from the Gold Coast, and around this time her awareness of Africa as offering a potentially unifying identity for black people in all continents emerges in her work. Her editorial in The Keys, which appeared in the first quarter of 1935, offers a general message of unity and collective gain for people of African descent and calls for collaboration and reciprocal education for the betterment of the race.

The Negro world must come together ... And who is going to do these things for us? We have got to do it ourselves - if we can co-operate ... if every educated Negro will feel the burden of his brother is too great for him and help him to carry it - then things will be done. Then, and only then will the Negro race be a race contributing richly to the world. ${ }^{7}$

At this same time, Marson was taking a public platform on the issue of women's rights. In 1934 she gave a speech at the Women's International League Conference in London. In 1935 she was the first Jamaican invited to speak at the International Alliance of Women for Suffrage and Equal Citizenship Conference in Istanbul. On this occasion, as others, Marson used her platform at women's organisations to argue for black liberation. Indeed, if she had travelled to London to claim her equal citizenship as a woman - as her early journalism in Jamaica may suggest, "This is our age - we have won the freedom we have been fighting for, let us use it to the full advantage' - then Britain, with its blatant racism, demanded a more complicated and plural understanding of fights for freedom. ${ }^{8}$ It was in this context, compelled by her growing awareness of Pan-African movements and the political urgency of contesting racial hierarchies, that Marson initiated the discourse on mutual liberation that is arguably her most significant intellectual contribution: 'Negroes are suffering under enormous difficulties in most countries of the world. We must count upon all countries where there are Negroes - for women always possess a better developed sense of justice - to obtain for them a life more pleasant and less severe. ${ }^{19}$

Later that year, Marson was the first black woman invited to attend the League of Nations at Geneva and her meeting there with the Abyssinian delegation made a great impact on her. Marson was outraged by Mussolini's invasion of Abyssinia in 1935, and moved to action: 


\section{ALISON DONNELL}

I was anxious to do something for Abyssinia but people said it was unwise to go out to Ethiopia and they suggested that I go and assist in the Legation in London.

I went straight back to London and went to the Legation where I met Dr. Martin, the Ethiopian Minister, and they had a colossal amount of work as they did not have a regular typist to handle their correspondence. I said that I was anxious to help but they said they had not much money and I said that I did not mind and I worked there right through the war. I studied the country and lectured on behalf of Ethiopia in England. ${ }^{10}$

She went on to work as personal secretary to Haile Selassie, with whom she travelled to Geneva. However, by September of 1936 she was severely depressed and unable to continue. In an interview with The Gleaner on her arrival back in Jamaica, Marson admitted 'The position of Ethiopia is very heart-breaking and the tribulations of the Ethiopians have cracked me up ${ }^{\prime} .{ }^{11}$ Although by now the idea of transnational black alliance was integral to Marson's intellectual convictions, the emotional consequences of her empathetic link with others' suffering, which she claimed gave women a privileged access to an understanding of injustice, had exerted a negative effect on her health.

Although her time spent in Britain had enabled Marson to develop her ideas on African unity and women's rights, her work also discloses her difficulty and unease in challenging the authority of the metropole or European culture at close quarters. Indeed, her writings which reflect on her time spent in England offer us both a condemnation of racism and a testimony to its effects. In an article for the News Chronicle in 1934 she speaks of racism as a form of disarticulation: 'In America they tell you frankly where you are not wanted by means of big signs, and they don't try to hide their feelings. But in England, though the people will never say what they feel about us, you come up against incidents which hurt so much that you cannot talk about them. ${ }^{\prime 2}$ This inability to articulate her political convictions with force in a British context, here the League of Nations Conference, is made very clear in 'Traitors all!', where she describes her sense of injustice and outrage at the lack of a protective quota for the colonies and Jamaica.

I felt like getting up in the conference and screaming out that such was the loyalty with which some Jamaicans had chewed and digested the Union Jack that Jamaica had not been able to enter at all into their system. Instead, I crept up to the platform after the Session like a worm and had a talk with Mr Beresford, who told me he had not fully realised that there was any Colony anxious for such a Quota. ${ }^{13}$

Marson's honesty in registering her own reticence and sense of powerlessness in Britain helps us to appreciate the kinds of subtle as well as direct oppression that racism generates. ${ }^{14}$ 


\section{UNA MARSON}

Nevertheless, being back home was no respite from tribulation. Marson had returned to Jamaica, which had been hit even harder than other West Indian islands by the economic depression of the 1930s, at a time of intense social and political unrest. However, the climate of political ferment and the promise of change appear to have restored her voice and her commitment to politics, as by 1937 she had a regular column in Public Opinion. This weekly paper, started in 1937 and affiliated to Norman Manley's People's National Movement, foregrounded issues of cultural politics, was soon staffed by many of the island's culturally active women: Edna Manley was editor, Una Marson and Amy Bailey were board members and Gloria Escoffery, 'artist and poet', was the editor of the literature page. ${ }^{15}$ Marson's journalism of this period reveals a voice that is strident, polemical and radical, and this two-year period spent in Jamaica is arguably the high point of her intellectual career, when she was writing regularly on issues that really mattered to her, with energy and clarity. A combination of factors - being back in Jamaica; being part of a majority; and being witness to the unrest of her people at home - meant that from 1937 her work was overtly, loudly political.

It was at this point that Marson's work most emphatically fulfilled James's call for West Indians 'to place ourselves in history'. ${ }^{16}$ For Marson, Jamaicans could only come to know themselves as historical subjects by disconnecting themselves from false notions of white ancestry and reconnecting to their African past. Although she herself had an Irish great-grandfather, she chose not to play to this heritage and admonished others who did.

The point I want to make is that educated Jamaicans spend their whole lives thinking they are not coloured, and it is an insult to call them 'Negro' because one or two generations back they had some white ancestor of the male sex. Now we can never be free from inhibitions, complexes, indecision and lack of confidence until we accept ourselves for what we are. ${ }^{17}$

At a time when eurocentric ideals of beauty, morality and culture were championed in middle-class Jamaica, Marson sought to position a new politics of identity through the connection to Africa. In the face of 'Many Jamaicans [who] would like to rewrite the social history of Jamaica to prove that they have no Negro blood in their veins', Marson herself mapped a new history for an emergent nation, a history that denounced racism, which she identified as a West Indian predicament. ${ }^{18}$ In '"But my own"', her most polemical piece for Public Opinion, Marson connected the denial of Africa to the estrangements and limitations of colonial dependence. 


\section{ALISON DONNELL}

Is Jamaica to be allowed to remain in the morass of indifference to cultural matters and true education? ... Are we the younger generation to remain resigned to the sham and shallowness of the artificial life into which we have been cast? Are we to remain strangers in our own land, eaters of the crumbs that fall from the tables of others when we have it in our power to sit at a table well garnished by our own hands? ${ }^{19}$

Although Marson's immediate goal was the cultural and political transformation of Jamaica, her connection with Africa, especially Ethiopia and the Gold Coast, via England, had clearly provided a new lens through which to refine her ideas of cultural identity. Indeed, what was so significant about Marson's experience in Britain was that it had given her a wider frame through which to view the issue of national self-representation, as well as the links between colonial and national politics.

By the time the social conditions in Jamaica became critical and protests became violent, Marson was reporting for the Jamaican Standard. Although engrossed by the drama of the labour rebellions and by their challenge to colonial power, she remained concerned about welfare issues and once again turned to a more direct mode of service, raising money for a Jamaica Save the Children Association. ${ }^{20}$ Seeking not only to argue for change, but to work for it as well, she returned to London in order to report on and to the Moyne Commission, to raise money for Jamsave and generally to stimulate awareness about the situation in Jamaica. Although she had been keen to point out the responsibilities that Jamaicans had to claim their rights and freedoms within a Jamaican context, in London she took on the role of advocate. At a meeting of the League of Coloured Peoples, 'Miss Marson further emphasised the need for help and appealed to her audience to let people outside know what the poor people were suffering in Jamaica owing to neglect'. ${ }^{21}$

After the declaration of war in 1939, Marson witnessed changes in the black community in Britain: fewer students came and many of those based in London now moved north. In an undated article written during wartime, she paid special attention to the predicament of the 'coloured woman'. Drawing on her own situated knowledge and that of others, she pointed to the effects of racism, but the voice of her Jamaican polemics is somewhat subdued.

The young coloured woman has to face many problems. More often than not she is poorly educated and she finds the problem of finding work a serious one ... In London, most avenues of work except that of entertaining in the dance or Music halls, are closed to coloured people ... I know of their difficulties and I myself have experienced difficulty in finding work when I urgently needed it. Once I tried to register for work as a ste- 


\section{UNA MARSON}

nographer. One agent told me she didn't register black women because they would have to work in offices with white women. Another agent tried to find me a position and he told me that though my references were excellent firms did not want to employ a black stenographer. ${ }^{22}$

Marson's own fortunes improved when she took freelance work with the BBC and in 1941 was appointed full-time programme assistant for the BBC's Calling the West Indies which evolved into the now famous Caribbean Voices. Here again, Marson was able to establish avenues through which peoples and cultures could speak to each other and realise the ideal of collaborative effort and mutual education that underpins many of her projects. Although accounts commonly suggest that Henry Swanzy had the main hand in nurturing and directing West Indian writing, in fact, by the time Marson returned to Jamaica in 1945, she had already established an important forum for literary expression that drew on her local knowledge of the literary culture, which she had gained through her contacts with the Jamaican Poetry League and Focus, the successor to Public Opinion. She was, at the time, suffering from another severe episode of depression and was eager to return to the West Indies and come to know the islands and people with whom she had become familiar across the airways. Marson was not present at the 1945 Manchester Pan-African Congress, but she did meet Eric Williams, among other prominent West Indians, in New York, where she made a stop on her journey home. ${ }^{23}$

The fact that on Marson's return to Jamaica in 1945, 'everywhere she went, huge crowds gathered as though she were royalty', and that a lunch in her honour organised by the Poetry League of Jamaica was attended by Edna Manley and Roger Mais, amongst others, speaks of the high profile and recognition that she was accorded within her lifetime. ${ }^{24}$ After a brief return to London, and thence a prolonged recuperation from ill-health and depression, in 1949 Marson became organising secretary for the Pioneer Press, the book-publishing department of the Gleaner. The Pioneer Press was the first serious Jamaican publishing house and redressed the great absence of publishing facilities within the West Indies that so many writers subsequently bemoaned when explaining their reasons for migration to the metropolis. This focus on local, committed publishing was another crucial step in the development of West Indian literature that Marson had helped to advance, this time on home soil. Its programme outlined a new emphasis upon the recognition and promotion of local literary talent: 'The Pioneer Press seeks to serve the literary ambitions of the people of Jamaica in an organised way by publishing the meritorious work of local authors'. ${ }^{25}$

For Marson, this project represented the links between literary 


\section{ALISON DONNELL}

expression and cultural development that she had identified as being a significant absence in Jamaica back in 1937. In 'Wanted: writers and publishers', in Public Opinion, Marson had called for local publishing ventures that could foster links between nationalism and writing, the sharing of local knowledge and the need for self-scrutiny:

We are passing through the birth pains of bringing forth a new Jamaica. In this new era literature must take its place. Indeed, the writing and production of books by us about ourselves and our problems is essential ... Now in Jamaica we have no publisher. I have known of two books written by Jamaicans who tried to get them published in England ... I am sure that if we had a publishing house in Jamaica books that would do us credit would be published annually. Can we get anything done about this? ${ }^{26}$

There is a note of irony in the fact that by the time Marson was able to help establish a Jamaican publisher the fortunes of West Indian writers in the metropolis had changed somewhat, partly due to her own efforts in establishing Caribbean Voices. For Marson, bringing 'authentic' and local voices into print was high on the agenda of cultural nationalism and the fact that Pioneer Press were the first to publish work by the 'nation-language' writer Louise Bennett in 1949, decades before she would receive widespread critical acceptance, is testimony to Marson's radical understanding of cultural value at this time.

Although Marson did not return to London until 1964, just one year before her death and two years before the formation of the Caribbean Artists Movement, there is a sense in which Britain, as the colonial motherland, had been the catalyst for her many journeys, providing both the political and intellectual impetus behind the internationalism and transnationalism that was so crucial to the freedom movements of this time. Being in London during the 1930s and 1940s had enabled Marson to realise the Pan-African dimension of her thinking and had brought her into contact with a network of liberation movements congregated in Britain at this time. For Marson, as for other West Indians living through this period in Britain, there was a strong sense that history necessitated their movements, the journeying that colonialism had set in motion was now being replayed in a climate of highlycharged political restlessness and mobility that was to change profoundly the national identities and cultures of both Britain and its West Indian colonies. In her later years Marson continued to travel, spending 1952 to 1960 in the US. By the time she returned to London in 1964 she was able to appreciate that a very different cultural and literary scene had emerged but she remained cautious about the freedoms and opportunities open to West Indians in the metropolis.

Although recorded history has left us little evidence by which to 
judge how other West Indian intellectuals in Britain thought of Marson or reacted to her ideas, the close network of personalities, organisations and places through which those who were black and in Britain moved during the 1930s and 1940s also leaves little doubt that Marson must have met and engaged with many of the intellectuals of her time. As assistant secretary to the League of Coloured Peoples, she not only had close contact with its president, Harold Moody, but must have encountered C. L. R. James, whom The Keys described as a 'brilliant young $\mathrm{man}^{\prime}$ in the editorial to their first issue, and whose 'eloquent address was followed by a lively discussion', at their first conference in March 1933. By a similar token, she is likely also to have known and talked with Padmore, who was a friend of Moody (as well as of James) and who visited the Moody family home where Una first lodged. It is regrettable that we know nothing in detail of how Marson and the young radicals James and Padmore viewed each other, especially since she seems to have made a strong impact on those who did know, or know of, her.

Her fellow Jamaican, Marcus Garvey, was aware of Marson and her experience of Britain by 1933, when she had only been in the metropolis for a year. Indeed, Garvey uses Marson's own disillusionment with Britain in order to exemplify his theory that black people had not anticipated the racism of the metropolitan motherland.

Our countrywoman Miss Una Marson went to England some time ago to be disillusioned. She thought she was going to a country where she would be accepted on equal terms with those who built it, and made its civilization possible. Like most of our race, she thought we have nothing else to do than to project ourselves into the civilization of other people and to claim all its rights. When she found a contrary attitude, she rebelled and wrote some very nasty things about the English. ${ }^{27}$

It is possible that Garvey was referring to Marson's poem 'Nigger' which was published in the first issue of the Keys in 1933 and remained her strongest critique of English racism. Garvey's observation of Marson is interesting in its claims for her optimistic attitude towards metropolitan life as, although already 'race conscious', Marson had written mainly about gender inequality before coming to England. Her early writings in Britain did register her shock and distress at encountering racial abuse and prejudice, reactions that would soon inform her renegotiated ideas of freedom struggles and collective campaigning as she shifted towards a more deeply anti-racist and nationalist politics.

As more research is conducted on women intellectuals and nationalists during this period, their links to each other will become clearer and that two-way conversation with history will begin to emerge more clearly. One such link, between Maida Springer, an activist in 


\section{ALISON DONNELL}

American and African labour movements, and Una Marson, has come to light recently. ${ }^{28}$ Springer first met Marson on the Caribbean Voices programme and their encounter, in the early 1940s, was important to Springer who was soon to meet Padmore and form a close political association with him, and, through Padmore, gain an introduction to Ras Makonnen and Jomo Kenyatta. In Marson, Springer met a woman of her own generation (she was born 1910) who was determined in her political convictions and committed to women's emancipation. Moving mainly within the male-dominated circles of international labour movements and Pan-Africanist organisations, Springer, who was herself very concerned to address women's inequalities and acknowledge their nationalist activities, was impressed by Marson. Springer recalled a night spent in Marson's flat in the company of African and Caribbean soldiers:

They had no illusions about what they were doing and for the most part - because I think Una was very selective about the people she invited these were men who had a vision of the future and they were looking to the day when they were going to have a country, not a colonial dependency. So it was very good to talk at night. Very explosive talk! Had they been heard, they would all have been court-martialled. ${ }^{29}$

Although the prospect of court-martialling may seem dramatic, it is important to remember that Roger Mais was imprisoned in Jamaica on charges of sedition in 1944. ${ }^{30}$ Springer's recollection reminds us of the depth of Marson's anti-colonialism during this period.

Positioned at either end of Marson's time spent in England, these two reports of her activities and associations - by Garvey and by Springer suggest that it was her unequivocal condemnation of the domestic culture of the imperial nation-state that made an impact on others. While these convictions remained strong, a close examination of her journalistic and creative writing from the 1930s, through wartime and beyond, foregrounds Marson's persistent effort to bring issues of gender inequality into political agendas and movements for social change.

\section{Woman and intellectual}

Men in the past have never been over partial to intellectual women but today mental development is essential. ${ }^{31}$

A man is never a career man ... But the woman is called career woman because her 'career' in modern society demands she place herself in a subordinate position or even renounce normal life. The social dice are loaded against her; and even the plain fact of the matter is that they are loaded not only in the economic opportunities, but in the minds of men. ${ }^{32}$ 


\section{UNA MARSON}

Throughout her life Marson sought out forums for the exchange and collectivity of ideas - in her journalism, lectures and organisational work, she was opening her ways of seeing to others in the hope that they might respond in kind. At the beginning of her career she was specifically concerned that women begin to view themselves as political beings with social responsibilities and rights. Although her editorials for the Cosmopolitan were directed at professional (middle-class) women, she consistently encouraged them to think and act beyond the assumed protocols and routines of their lives. In her 1929 article, 'Jamaica's victory', she seeks to answer newspaper criticism of the modern Jamaican woman for wearing make-up and short skirts by arguing that women should take their freedoms seriously and use them responsibly. Already, at the age of twenty-four, she had a strong sense of what could be achieved by liberated women who took up their place in history:

Is it not possible for the women of Jamaica to realise what a gift is theirs to be living in an age where there can be no limit to what they may achieve? ... It is a privilege to be living in an age such as this. History is bound to repeat itself. With the wonderful progress of civilisation all our problems have not been solved - there is great work ahead for the good of humanity, and women are to play a great part in that work. No more must we be regarded as toys - but women of foresight, strength and skill. Women who can forget self in the work that lies ahead for the good of humanity. ${ }^{33}$

Marson also insisted that action, as well as conviction, was the pathway for women to achieve change: 'A big rally of women workers would be the best thing to sweep the cobwebs from certain brains and dust out the eyes so they can see better'. ${ }^{34}$

Indeed Marson's own priorities for a feminist agenda (awareness of inequality, responsibility to others, collaboration and public action) were already in place before her first visit to London in 1932. It is also significant that back in Jamaica in 1937, she reported favourably on the collaborative success of women in Britain and described her own participation as part of a larger collective project. Feminism was not a politics that she first encountered or adopted in England - although she was eager to promote the positive experience of women's organisations, using her first interview after returning to declare that:

England is a wonderful country for its women's organisations ... I got in touch with the British Commonwealth League, the Women's Freedom League, The Women's Peace Crusade, the Women's International League, the International Alliance for Suffrage and all these women's associations get together ... I was invited to go to Turkey to the great Congress of the International Alliance of Women for suffrage and citizenship which is 


\section{ALISON DONNELL}

held every three years. There were three hundred women present, representatives of thirty countries ... We all came together as though we were one big family and it was wonderful to see how everyone was eager to learn something of other countries. ${ }^{35}$

In order to understand her emphasis here it is important to recognise that in the Jamaica that Marson had left in 1932, women's organisations had a quite different political currency. The Social Purity Association of Jamaica, formed in 1917, and the 1918 Women's Social Service Club did not work to liberate women in any meaningful way, but rather served to reinforce their position within a male-dominated society and to establish codes of behaviour which corresponded to traditionally eurocentric concepts of femininity. Even the first black women's society, the Jamaica Women's Liberal Club, formed during the period when Marson was writing for Public Opinion, was governed by a profound social conformity. In this context, then, Marson's ideas of what might be achieved by women's organisations in Jamaica was informed by her experience of Britain, but also calibrated against her experience of home.

In terms of understanding the reciprocal routes of intellectual exchange between the West Indies and Britain, I would contest Delia Jarrett-Macauley's conclusion that 'Una's proposals for Jamaican feminist activism as propounded in Public Opinion consisted largely of a reworking of initiatives she had witnessed and admired in England'. ${ }^{36}$ Marson did bring ideas and inspirations back to Jamaica and - having described the public debates pressed by five British women (Eleanor Rathbone, Erina Reiss, Mrs Oliver Strachey, Alison Neilans and Mary Agnes Hamilton) - she did commend Jamaican women to 'take a leaf out of their book'. ${ }^{37}$ Nevertheless, she did more than transport these ideas and strategies from one locale to another; she was actually transforming her ideas on women's liberation in the light of her growing understanding of racial antagonism, the politics of anti-colonial movements and the potentially unifying connection to Africa, all of which she developed as a result of living in Britain.

The opposing ideologies of racism and Pan-Africanism that Marson had encountered in Britain led her to work through a new politics of identity and agenda for social justice. Both her creative and her journalistic work testify to her capacity to synthesise the politics of feminism and the politics of anti-colonialism, translating each into the other. In most of her articles that address women's rights, Marson refers to the issue of racial hierarchies and to the importance of self-determination:

There is a crying need for a few feminists, wide awake to the needs of the corporate area, to sit on the City Council ... the need for women in our 


\section{UNA MARSON}

Legislative Council is even greater. Our women should be there, our women must be there in the near future ... Why is it that the social work that is being done in Kingston ... remains in the hands of a few members of the older set, who are for the most part English people or women from Jamaica's white social circle?'38

We cannot expect people from abroad to be more interested in us than we are in ourselves ... WE do not need an expert from abroad to tell us that we can collect money and appoint women in every part of the island to work among children. ${ }^{39}$

However, as Jarrett-Macauley points out, Marson's intellectual interventions on women's rights were not necessarily appreciated and her insistence led to her being seen as out of step with the 'positive ideas' of the day by those who could have been her political allies. Although her voice was now strong on these issues there was no community, intellectual or political, receptive to her ideas:

She was the one always pushing the woman question but who never had any constructive ideas other than the assertion that women must speak up ... I used to think her speeches a bit empty of content, I don't think she was very much in tune with the positive ideas that were coming up, the idea that we should rule our own country and that sort of thing, the idea of promotion of culture. ${ }^{40}$

Marson was a committed cultural nationalist and had a wealth of positive ideas. What Richard Hart's estimation reflects is how irrelevant, distracting and even unwelcome her insistence on the 'woman question' was seen to be in Jamaica of the late 1930s. Seeking to expand and refine the narrow nationalist agendas of this time, Marson was perceived only to be missing the point.

The fact that Jamaica was not ready to listen to her calls was evident in other ways too. The wider field of state power after 1938 still functioned as a powerful agency of patriarchal power. Married women were not allowed to pursue careers as civil servants, the school curriculum was revised to promote female education as matrimonial training in 1939, and the 1941 Committee on Concubinage and Illegitimacy recommended that working-class women be directed into domestic duties.

In Britain of the 1930s and 1940s, Marson's interest in the woman question was less exceptional and she found many audiences and like minds in the organisations she joined and in those she addressed. Nevertheless, her ability to open out debates about inequality and injustice to the politics of colonial rule and the operations of racism should not be underestimated. This is not to argue that Marson initiated a 


\section{ALISON DONNELL}

tradition of black British feminist thought. Indeed, it is difficult to construct a continuous genealogy of black British feminist thought when, as Mirza points out, 'concerted black feminist activity in Britain reaches back only over the last 50 years' ${ }^{\prime 4}{ }^{41}$ It is to suggest, though, that Marson was well placed to comprehend British society in ways that James and the other male figures were not, and that her observations and interventions, particularly those which focused on the liberation of women, were both distinctive and combative. Indeed, given that the demands for British feminism to account for race are conventionally traced back to Hazel Carby's 1982 essay 'White woman listen! Black feminism and the boundaries of sisterhood', Marson's insistence upon gender and race as mutually affective identity categories was both innovative and intellectually challenging. ${ }^{42}$

The absence of Marson from most literary and cultural histories is lamentable. She was a woman of extraordinary creativity and ambition, qualities that she directed towards the great causes of her time: the advancement of women's rights; the struggle against colonialism; and the strengthening of cultural and literary nationalism. However, if Marson is now becoming an acknowledged figure, what about other 'critical women' from the Caribbean who are still waiting for history to write the narratives into which they can be accommodated? ${ }^{43}$ Although Marson was clearly an exceptional woman, she was not unique. A consideration of other West Indian women intellectuals in Britain proves that there was a small number who were passionately involved in the burning political and cultural issues of the day, and who - in so doing - created new modes of thought. While more research is emerging on women's histories, there remains an unspoken tension in many accounts around the issue of gender politics and the naturalised tendency towards centring male activity and thought.

A striking example of just this can be found in Simon Gikandi's representation of Amy Ashwood Garvey.

In the late 1930s and 1940s, so the story goes, a group of colonised black intellectuals, whom I have come to call the Afro-Victorians, used to meet regularly at a restaurant owned by Mrs Amy Garvey on Oxford Street in London ... The men and women who met in Mrs Garvey's restaurant were working under the shadow of colonialism, its technologies of domination and its polity, but their desires were informed by a fundamental belief that they were the vanguard of a movement towards a decolonised future. ${ }^{44}$

Despite the inclusive description of 'men and women', the only women Gikandi mentions by name are Queen Victoria, Elspeth Huxley and Mrs Amy Garvey. The article goes on to list George Padmore, C. L. R. 


\section{UNA MARSON}

James, Ben Nnamdi Azikiwe, Francis Kwame Nkrumah and Johnston Jomo Kenyatta as the key players in discussions on Pan-Africanism. Gikandi does not even make it clear which Mrs Amy Garvey he is discussing here, Amy Ashwood Garvey, Garvey's first wife, or Amy Jaques Garvey, his second. Moreover, there are no footnotes to the story about Mrs Garvey, her politics, or even her restaurant. She is just the backdrop, her restaurant the venue for the real story that is to be told, the story of meetings of men and men's minds.

The way in which Amy Ashwood Garvey functions as a narrative opener, literally positioned at the margin of this piece, is less forgivable given that this 'Mrs Garvey' was among the close network of West Indian and African intellectuals who were working together for the International African Friends of Abyssinia. ${ }^{45}$ Her speech to the 1945 Pan-African Congress in Manchester conveys both her specific and direct interest in the gender politics of political movements and - ironically - predicts her own historical fate: 'Very much has been written and spoken of the Negro, but for some reason very little has been said about the black woman. She has been shunted into the social background to be a child-bearer. ${ }^{\prime 46}$ Half a century later, the history of women's contribution to a West Indian intellectual tradition is still not fully represented.

Now emerging from the background, Marson merits serious attention as a political intellectual and as an imaginative writer. Her substantial contribution stems from her awareness of the collocation of African subjects and women within the political matrix of British colonialism. Although many of Marson's ideas were based on the ethical obligations and possibilities for mutual empowerment that bonded Africans and women to each other, what was most daring about her contribution was her willingness to break the masculine consensus of the West Indian intellectual community. In so doing, she could see colonial authority from a quite new perspective, and grasp too the deep complexities of the colonial civilisation of the British. Although in retrospect this insight can be judged as of inestimable value, being out of step with the prevailing politics of her day has, to date, cost Marson a place in most histories of political and intellectual change.

\section{Notes}

1 Delia Jarrett-Macauley, The Life of Una Marson, 1905-65 (Manchester: Manchester University Press, 1998), p. 19.

2 See Alison Donnell, 'Sentimental subversions: the poetics and politics of devotion in the poetry of Una Marson', in Vicki Bertram (ed.), Kicking Daffodils: essays on twentieth-century women's poetry (Edinburgh: Edinburgh University Press, 1997), pp. 113-24; Alison Donnell, 'Contradictory (w)omens? Gender consciousness in the poetry of Una Marson', Kunapipi, XVII (1995), pp. 43-58. 


\section{ALISON DONNELL}

3 'Racial prejudice in London not improving says Miss Marson', Daily Gleaner (28 September 1936), p. 5.

4 Una Marson, “"But my own"', Public Opinion (19 June 1937), pp. 3 and 15.

5 George Lamming, The Pleasures of Exile (London: Michael Joseph, 1960), p. 41.

6 See John McLeod, 'A night at "The Cosmopolitan": axes of transnational encounter in the 1930s and 1940s', Interventions: International Journal of Postcolonial Studies, 4:1 (2002), pp. 53-67.

7 Una Marson, The Keys, 2:3 (January-March 1935), pp. 45-6.

8 Una Marson, 'The age of woman', Cosmopolitan, 1:11 (March 1929), p. 65, in Linette Vassall (ed.), Voices of Women in Jamaica, 1898-1939 (Kingston: University of the West Indies Press, 1993), pp. 24-6.

9 Jarrett-Macauley, Life of Una Marson, p. 90.

10 'Jamaican girl who was personal secretary to Haile Selassie', Daily Gleaner (25 September 1936), p. 17.

11 'Jamaican girl', p. 17.

12 News Chronicle (15 June 1934), in The Keys, 2:1 (July-September 1934), p. 54.

13 Una Marson, 'Traitors all!', Public Opinion (18 September 1937), p. 5.

14 See also Una Marson, 'A call to Downing Street', Public Opinion (11 September 1937), p. 5 .

15 Cedric Lindo, private letter to Alison Donnell (22 December 1990).

16 C. L. R. James, 'The West Indian intellectual', introduction to J. J. Thomas, Froudacity: West Indian fables by James Anthony Froude (London and Port of Spain: New Beacon Books, 1969), pp. 47 and 45.

17 Una Marson, 'Racial feelings?', Public Opinion (17 July 1937), p. 3.

18 Una Marson, 'I can tell you what's wrong with Jamaica says Una Marson', Daily Gleaner (17 February 1951), p. 9.

19 Marson, "'But my own"', p. 15.

20 Jarrett-Macauley, Life of Una Marson, p. 139.

21 'BWI affairs topic of talk at League meeting in England', Daily Gleaner (1 October 1938), p. 10.

22 'Problems of coloured people in Britain', no date, Una Marson Papers box 1944C, p. 1.

23 'Una Marson on visit home', Daily Gleaner (18 August 1945), p. 15.

24 Jarrett-Macauley, Life of Una Marson, p. 169.

2514 Jamaican Short Stories (Kingston: Pioneer Press, 1950).

26 Una Marson, 'Wanted: writers and publishers', Public Opinion (12 June 1937), p. 6.

27 Marcus Garvey, New Jamaican (20 February 1933), in Rupert Lewis and Patrick Bryan (eds), Garvey: his work and impact (Mona, Jamaica: ISER, University of the West Indies, 1988), p. 232.

28 Yvette Richards, 'Race, gender, and anticommunism in the international labor movement: the Pan-African connections of Maida Springer, Journal of Women's History, 11:2 (1999), pp. 53-67.

29 Richards, 'Race, gender and anticommunism', pp. 45-6.

30 Mais's article, 'Now we know', Public Opinion (1 July 1944), was considered capable of inciting disaffection during wartime.

31 Una Marson, 'Feminism', Public Opinion (10 April 1937), p. 10.

32 C. L. R. James and Anna Grimshaw, The C.L.R. James Reader (Oxford: Blackwell, 1992), p. 144, quoted in Ato Quayson, Postcolonialism: theory, practice or process? (Cambridge: Polity Press, 2000).

33 Una Marson, 'Jamaica's victory', Cosmopolitan, 2:2 (June 1929), pp. 66-7.

34 Marson, 'Jamaica's victory', pp. 66-7.

35 Marson, 'Racial prejudice in London', p. 5.

36 Jarrett-Macauley, Life of Una Marson, p. 114.

37 Una Marson, 'Some things women politicians can do?', Public Opinion (27 February 1937), p. 10.

38 Una Marson, 'Should our women enter politics?', Public Opinion (20 February 1937), p. 10, emphasis added.

39 Una Marson, 'We must save the children', Public Opinion (13 March 1937), p. 10. 


\section{UNA MARSON}

40 Richard Hart, quoted in Jarrett-Macauley, Life of Una Marson, p. 115.

41 Heidi Safia Mirza (ed.), Black British Feminism: a reader (London: Routledge, 1997), p. 6.

42 Hazel Carby, 'White woman listen! Black feminism and the boundaries of sisterhood', in Centre for Contemporary Cultural Studies, The Empire Strikes Back: race and racism in 70s Britain (London: Routledge, 1982).

43 In particular, the Jamaican, Amy Bailey, and Dominican, Phyllis Shand Allfrey, who both spent time in London.

44 Simon Gikandi, 'Pan-Africanism and cosmopolitanism: the case of Jomo Kenyatta', English Studies, 43:1 (2000), p. 3.

45 See Peter Fryer, Staying Power: the history of black people in Britain (London: Pluto Press: 1984), p. 345.

46 Fryer, Staying Power, p. 350. 